\title{
Therapy of West Nile Virus Infection
}

Can. J. Neurol. Sci. 2004; 31: 131-134

There was an incursion of West Nile virus (WNV) into the New York City area of the United States in $1999^{1}$ and subsequently there has been rapid geographic expansion through the North American continent with human cases occurring in Canada during both the $2002^{2}$ and 2003 seasons. Clearly, WNV infection has now become endemic in wild birds and there will continue to be a threat for transmission to humans via mosquitoes during the summer and fall months on a yearly basis. Most WNV infections are subclinical or cause only a mild systemic illness without neurological manifestations. In a minority of individuals WNV infection has been recognized to be associated with a variety of neurological syndromes in addition to the relatively common presentations with encephalitis and aseptic meningitis. Patients may develop asymmetrical flaccid muscle weakness, frequently with respiratory muscle involvement, due to myelitis (poliomyelitislike) with infection of spinal cord motor neurons and/or involvement of ventral nerve roots. ${ }^{3-5}$ Optic neuritis ${ }^{6}$ and a variety of movement disorders, ${ }^{7,8}$ cerebellar syndromes, and other neurological problems have been associated with WNV infection. In this issue of the journal, Sayao et $\mathrm{al}^{9}$ have made the first report of WNV infection presenting with the opsoclonusmyoclonus syndrome.

Therapy of patients with WNV encephalitis or encephalomyelitis is a challenging problem facing neurologists and infectious disease specialists. Therapy of flavivirus infections has been only supportive since there are no available antiviral or other drugs with proven efficacy. Ideally, studies of potential therapies should first be assessed in good animal models with neurological disease before they are used for the treatment of human disease. The lack of data from animal studies and the abundance of human cases during 2002 and 2003 have led to the use of therapeutic agents without the benefit of this important information. The most promising potential treatment options that are available at the present time for human therapy include ribavirin, interferon- $\alpha$, anti-WNV immunoglobulin, and genetargeted technologies. Each of these therapies will be discussed individually.

\section{RIBAVIRIN}

Ribavirin is a synthetic nucleoside analogue and a RNA mutagen $^{10,11}$ with in vitro activity against several viruses. Ribavirin also has immunomodulatory properties that may, in part, account for its antiviral properties in vivo. ${ }^{12}$ Ribavirin has in vitro activity against WNV infection, although efficacy has not yet been demonstrated in an animal model. Ribavirin has antiviral activity at high doses in vitro, inhibiting viral replication and cytopathogenicity, with a measured $\mathrm{ED}_{50}$ of $60 \mu \mathrm{M}$ (and $\mathrm{ED}_{90}$ of $190 \mu \mathrm{M}$ ) for reduction of extracellular viral RNA in human oligodendroglial cells. ${ }^{13}$ Lack of efficacy in central nervous system (CNS) viral infections may be attributed to failure of the drug to adequately cross the blood-brain barrier. Rapid uptake into cerebrospinal fluid (CSF) was not observed in rats and rhesus monkeys. ${ }^{14}$ Ribavirin has low lipid solubility with a partitian coefficient of -2.06 , resulting in ineffective passage through lipoid membranes. ${ }^{15}$ However, significant levels of ribavirin were observed in CSF after several weeks of oral ribavirin therapy in patients with AIDS and AIDS-related complex. ${ }^{16}$ Ribavirin is typically administered intravenously with both loading and maintenance doses. Administration of ribavirin intraventicularly via an Ommaya reservoir would be a therapeutic option for therapy of WNV infection at the present time, and this approach has recently been shown to be safe and well-tolerated for the treatment of subacute sclerosing panencephalitis (SSPE) ${ }^{17}$ No clinical trials of ribavirin in WNV infection have been reported. Thirty-seven patients received ribavirin in an outbreak in Israel in 2000 and high mortality $(41 \%)$ was noted in this group, but details of the therapy were not reported. ${ }^{18}$

\section{INTERFERON- $\alpha$}

Interferon- $\alpha$ is a natural immunoregulatory protein and an immunotherapeutic drug for viral and neoplastic diseases. ${ }^{19}$ Interferons provide a first line of defense against viral infections by generating an intracellular environment that restricts viral replication. Interferon- $\alpha$ interacts with cells of the innate immune system and participates in the transition into an effective adaptive-immune response, including antigen presentation for activation of cytotoxic T-cell responses. ${ }^{19}$ Interferon- $\alpha$ may also act synergistically with antibody, which has been demonstrated in Sindbis virus infection. ${ }^{20}$ Anderson and Rahal $^{21}$ have demonstrated in vitro inhibition of WNV-induced cytotoxicity with concentrations of interferon- $\alpha-2 b$ of $5.9 \mathrm{U} / \mathrm{mL}$ or higher when added 1.5 hours after infection. Surprisingly, interferon- $\alpha$ $2 \mathrm{~b}$ has not yet been evaluated in an animal model of WNV infection. ${ }^{22}$ A double-blind, placebo-controlled clinical trial in Vietnam failed to find a difference in mortality or functional outcome with intramuscular administration of interferon- $\alpha-2 \mathrm{a}$ (10 million units $/ \mathrm{m}^{2}$ body surface area daily for seven days) for treatment of Japanese encephalitis. ${ }^{23}$ Intravenous administration of interferon- $\alpha$ results in only low levels in the $\mathrm{CSF}^{24}$ and the systemic administration of a low dosage (vs. over 50 million $\mathrm{U} / \mathrm{m}^{2}$ used for SSPE and rabies encephalitis), which was initiated relatively late in the clinical course, may explain the lack of a therapeutic benefit. Intraventricular administration of interferon$\alpha$ and/or interferon- $\beta$ has been used for the treatment of SSPE. ${ }^{17,25}$ Therapy with interferon- $\alpha$ has been shown to be effective in a mouse model in preventing lethal infection with St. Louis encephalitis virus at around the time of exposure to the virus or shortly thereafter (reducing mortality by up to $70 \%$ ). ${ }^{26}$ However, late treatment was not effective in this model.

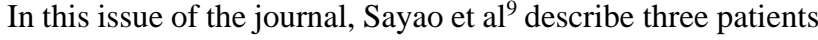


treated with open label interferon- $\alpha-2 b$. Although improvement of these patients gives us optimism that this therapy may be effective, only data from properly constructed clinical trials will give us useful information about the efficacy and safety of a therapeutic agent. A randomized unblinded clinical trial of interferon- $\alpha-2 b$ (Principal Investigator James Rahal, New York Hospital Queens, New York) has been initiated in the United States (http://nyhq.org/posting/rahal.html). Random enrollment of 40 patients is planned to either treatment with interferon- $\alpha-2 b$ (3 million units intravenously followed by 3 million units subcutaneously after 12 hours and then daily for 14 days) or to no treatment. Initiation of this study in 2002 was reported widely by the news media, including CNN. ${ }^{27}$

\section{ANTI-WNV IMMUNOGLOBULIN}

There is evidence that WNV may be susceptible to antibodymediated immune responses. In mice inoculated intraperitoneally with WNV, Camenga and co-workers ${ }^{28}$ gave cyclophosphamide to suppress the humoral and $\mathrm{T}$ cell-mediated arms of the immune response. The mice were then reconstituted with either immune serum or syngeneic spleen cells at various time points. Eighty-two percent of mice could be rescued at day 5 or 6 (virus detectable in the brain at day 6) with immune serum (vs. survival in $3 \%$ of controls), but not with syngeneic spleen cells. However, administration of immune serum at day 8 or 10 resulted in only $22 \%$ survival. In a model of WNV encephalitis in Syrian golden hamsters using intraperitoneal inoculation, viremia was detected for the first seven days after inoculation and neuronal degeneration was first noted by day 5 and death occurred in 50$70 \%$ of animals between seven and 14 days after inoculation. ${ }^{29}$ Antibody was protective when given 24 hours before inoculation in another study using the same model. ${ }^{30}$ However, if antibody administration was delayed until 48 hours after inoculation, then no survival effect was seen. ${ }^{22}$ Ben-Nathan and co-workers ${ }^{31}$ used an IgG preparation from human Israeli blood donors (anti-WNV antibody titer of $1: 1600$ by ELISA and of $>1: 80$ by plaquereduction test) and mouse anti-WNV hyperimmune serum (ELISAtiter 1:3200), which were administered intraperitoneally one day before and on day 1 and 3 after intraperitoneal inoculation of WNV. The human IgG preparation was also given in various regimens after administration of WNV, but always included a dose at day 3 or earlier after WNV administration. In this model viral invasion of the brain occurred about three days after inoculation of WNV. Survival of mice dropped to $50 \%$ when immunoglobulin was administered on day 3 and 4 . It is unclear if the therapeutic benefit was limited to administration of immunoglobulin during the viremic phase of the infection. Recently, Diamond and co-workers have reported experimental infection in adult C57BL/6 mice after footpad inoculation with the New York strain of WNV, and found viral spread into the brain on four to five days postinoculation. ${ }^{32,33}$ Administration of human gamma globulin containing anti-WNV antibodies reduced mortality when given as late as five days after viral inoculation. However, in this model clinical neurological disease did not develop until seven to 10 days postinoculation. ${ }^{32}$ Hence, administration of immunoglobulin only had a therapeutic effect when it was given at time points prior to the development of clinical neurological disease. In summary, there is not yet any experimental evidence that therapy with immunoglobulin will improve survival or neurological outcome of experimental animals when this therapy is initiated after the development of clinical neurological disease. Clearly, this is the important challenge in developing therapy for human disease.

In a model of experimental encephalitis in mice using infection with Sindbis virus, adoptive transfer of immunoglobulin was shown to result in clearance of infectious virus and viral RNA from the CNS. ${ }^{34,35}$ Furthermore, it was demonstrated that antiviral monoclonal antibodies could restrict viral gene expression in infected neurons. Administration of rabies virusneutralizing monoclonal antibodies (e.g., monoclonal antibody 1112-1) has also been shown to clear rabies virus infection from the CNS in a rodent model when administered before the onset of clinical signs, resulting in survival of experimentally-infected rats. ${ }^{36}$ This monoclonal antibody inhibited viral spread from cell to cell and restricted rabies virus RNA transcription. These experimental studies in animals indicate optimism that antibodies may potentially facilitate viral clearance from the CNS and promote resolution of neurologic injury. However, this effect has not yet been demonstrated in any flavivirus infection in humans or experimental animals. If there is an immunopathological component to the neurological disease, then administration of immunoglobulin could aggravate the clinical disease resulting in increased morbidity and mortality. Another concern is that progressive neuronal damage might occur after clearance of infectious virus, which has been recently shown by Kimura and Griffin ${ }^{37}$ after passive transfer of immune serum in experimental neuroadapted Sindbis virus encephalomyelitis in mice. Delayed or chronic neurological disease has also been observed after passive transfer of antibody in experimental measles virus infection ${ }^{38}$ and Semliki Forest virus infection ${ }^{39}$ in mice. For these reasons, studies should ideally be performed in animal models before therapies are given to patients or clinical trials are initiated.

There have been two reports of possible benefit of administration of intravenous immunoglobulin (IVIG) in immunocompromised patients. The first report was a 70-year-old female with a 12 year history of chronic lymphocytic leukemia. ${ }^{40}$ She progressed to coma within three days after the onset of her illness due to WNV infection and she had a CSF pleocytosis and IgM against WNV in both serum and CSF. She was treated with IVIG (Omr-IgG-am, Omrix Biopharmaceutical Ltd, Tel Hashomer, Israel) obtained from Israeli donors, $0.4 \mathrm{~g} / \mathrm{kg}$, and her level of consciousness returned to normal over five days. Because of the presence of endemic WNV infection in Israel, immunoglobulin preparations pooled from donors in Israel contain high titers of antibodies against WNV. A 42-year-old lung transplant recipient with serologically confirmed WNV encephalitis and deteriorating level of consciousness (described as confused and became more obtunded on the next day) received the same treatment and showed rapid improvement over 24 hours and his clinical disease resolved over 48 hours. ${ }^{41}$ Another 55-year-old male with chronic lymphocytic leukemia and recent chemotherapy developed generalized muscle weakness and memory impairment, which progressed to obtundation. ${ }^{42}$ There was serological confirmation of WNV infection and PCR on CSF was positive for WNV. He received five $0.5 \mathrm{~g} / \mathrm{kg}$ doses of Israeli IVIG (Omr-IgG-am) over a six-day 
period. He had persistent coma and magnetic resonance imaging showed progressive brain lesions, and he died 32 days into his illness. Hence, no beneficial effect of the therapy was demonstrated in this case.

The Collaborative Antiviral Study Group (Principal Investigator Richard Whitley, University of Alabama, Birmingham, AL) has initiated a phase I/II randomized, placebocontrolled trial to assess the safety and efficacy of intravenous IgG containing high anti-WNV titers in patients either with or at high risk for progression to WNV encephalomyelitis (see http://www.casg.uab.edu/ for a list of active sites in the United States). In this study hospitalized adult patients will be randomized to receive $\mathrm{Omr}-\mathrm{IgG}-\mathrm{am}^{\mathrm{TM}}$, an immunoglobulin containing no anti-WNV antibodies, or saline placebo. Initiation of this study in 2003 was also announced by the news media, including USA Today. ${ }^{43}$

\section{Gene-targeted Technologies}

Antisense compounds can be synthesized that recognize and bind to target viral gene sequences, resulting in a block in mRNA translation and protein synthesis. Recently, antisense technology using phosphorodiamidate morpholine oligomers has been applied to a number of emerging viral diseases, including infections caused by calcivirus ${ }^{44}$ and WNV. AVI Biopharma (Corvallis, Oregon) has developed an antisense compound, AVI4020, targeting WNV and has initiated phase I/II human clinical studies. During 2003 a total of 10 patients were enrolled in Colorado and AVI Biopharma reported no safety concerns (http://www.avibio.com/). Genetic-targeted technologies, including antisense compounds, hold promise for the future in the treatment of WNV and other viral infections.

\section{Combination Therapies}

It is possible that a combination of specific therapies may be more effective than single agents and this approach is being used for other viral diseases. For example, ribavirin and interferon- $\alpha$ provide a clinically synergistic effect in the treatment of chronic hepatitis $C$ infection. ${ }^{10,45,46}$ Combination therapy with intraventricular interferon- $\alpha / \beta$ and ribavirin has also been used for the treatment of SSPE. ${ }^{17,25}$ No reports have yet been published using combination therapy in WNV infection. Unfortunately, we do not yet have any therapies that are known to be effective for the treatment of WNV neurological disease. Hopefully, the results of studies in both animal models and in human clinical trials will soon become available.

Alan C. Jackson,
Kingston, Ontario

\section{REFERENCES}

1. Nash D, Mostashari F, Fine A, et al. The outbreak of West Nile virus infection in the New York City area in 1999. N Engl J Med 2001;344:1807-1814.

2. Pepperell C, Rau N, Krajden S, et al. West Nile virus infection in 2002: morbidity and mortality among patients admitted to hospital in southcentral Ontario. Can Med Assoc J 2003;168: 1399-1405.

3. Li J, Loeb JA, Shy ME, et al. Asymmetric flaccid paralysis: a neuromuscular presentation of West Nile virus infection. Ann Neurol 2003;53:703-710.
4. Sejvar JJ, Leis AA, Stokic DS, et al. Acute flaccid paralysis and West Nile virus infection. Emerg Infect Dis 2003;9:788-793.

5. Johnson RT, Cornblath DR. Poliomyelitis and flaviviruses (Editorial). Ann Neurol 2003;53:691-692.

6. Gilad R, Lampl Y, Sadeh M, Paul M, Dan M. Optic neuritis complicating West Nile virus meningitis in a young adult. Infection 2003;31:55-56.

7. Solomon T, Fisher AF, Beasley DW, et al. Natural and nosocomial infection in a patient with West Nile encephalitis and extrapyramidal movement disorders. Clin Infect Dis 2003;36: E140E145.

8. Sejvar JJ, Haddad MB, Tierney BC, et al. Neurologic manifestations and outcome of West Nile virus infection. JAMA2003;290:511515.

9. Sayao A-L, Patry D, Suchowersky O, et al. Calgary experience with West Nile virus neurological syndrome during the late summer of 2003. Can J Neurol Sci 2004;31:194-203.

10. Lau JY, Tam RC, Liang TJ, Hong Z. Mechanism of action of ribavirin in the combination treatment of chronic HCVinfection. Hepatology 2002;35:1002-1009.

11. Crotty S, Andino R. Implications of high RNAvirus mutation rates: lethal mutagenesis and the antiviral drug ribavirin. Microbes Infect 2002;4:1301-1307.

12. Tam RC, Lau JY, Hong Z. Mechanisms of action of ribavirin in antiviral therapies. Antivir Chem Chemother 2001;12:261-272.

13. Jordan I, Briese T, Fischer N, Lau JY, Lipkin WI. Ribavirin inhibits West Nile virus replication and cytopathic effect in neural cells. J Infect Dis 2000;182:1214-1217.

14. Ferrara EA, Oishi JS, Wannemacher RW Jr, Stephen EL. Plasma disappearance, urine excretion, and tissue distribution of ribavirin in rats and rhesus monkeys. Antimicrob Agents Chemother 1981;19:1042-1049.

15. Morrey JD, Smee DF, Sidwell RW, Tseng C. Identification of active antiviral compounds against a New York isolate of West Nile virus. Antiviral Res 2002;55:107-116.

16. Crumpacker C, Bubley G, Lucey D, Hussey S, Connor J. Ribavirin enters cerebrospinal fluid (Letter). Lancet 1986;2:45-46.

17. Tomoda A, Nomura K, Shiraishi S, et al. Trial of intraventricular ribavirin therapy for subacute sclerosing panencephalitis in Japan. Brain Dev 2003;25:514-517.

18. Chowers MY, Lang R, Nassar F, et al. Clinical characteristics of the West Nile fever outbreak, Israel, 2000. Emerg Infect Dis 2001;7:675-678

19. Brassard DL, Grace MJ, Bordens RW. Interferon-alpha as an immunotherapeutic protein. J Leukoc Biol 2002;71:565-581.

20. Despres P, Griffin JW, Griffin DE. Antiviral activity of alpha interferon in Sindbis virus-infected cells is restored by anti-E2 monoclonal antibody treatment. J Virol 1995;69:7345-7348.

21. Anderson JF, Rahal JJ. Efficacy of interferon alpha-2b and ribavirin against West Nile virus in vitro. Emerg Infect Dis 2002;8:107108.

22. Agrawal AG, Petersen LR. Human immunoglobulin as a treatment for West Nile virus infection (Editorial). J Infect Dis 2003;188:14.

23. Solomon T, Dung NM, Wills B, et al. Interferon alfa-2a in Japanese encephalitis: a randomised double-blind placebo-controlled trial. Lancet 2003;361:821-826.

24. Smith RA, Norris F, Palmer D, Bernhardt L, Wills RJ. Distribution of alpha interferon in serum and cerebrospinal fluid after systemic administration. Clin Pharmacol Ther 1985;37:85-88.

25. Hara S, Kimura H, Hoshino Y, et al. Combination therapy with intraventricular interferon-alpha and ribavirin for subacute sclerosing panencephalitis and monitoring measles virus RNAby quantitative PCR assay. Brain Dev 2003;25:367-369.

26. Brooks TJ, Phillpotts RJ. Interferon-alpha protects mice against lethal infection with St Louis encephalitis virus delivered by the aerosol and subcutaneous routes. Antiviral Res 1999;41:57-64.

27. Goldschmidt D. FDA gives nod to West Nile trial therapy. CNN.com/Health. August 22, 2002. Available at http://edition.cnn.com/2002/HEALTH/conditions/08/21/west.nil e.drugs/index.html (accessed on March 1, 2004).

28. Camenga DL, Nathanson N, Cole GA. Cyclophosphamide- 
potentiated West Nile viral encephalitis: relative influence of cellular and humoral factors. J Infect Dis 1974;130:634-641.

29. Xiao SY, Guzman H, Zhang H, Travassos da Rosa AP, Tesh RB. West Nile virus infection in the golden hamster (Mesocricetus auratus): a model for West Nile encephalitis. Emerg Infect Dis 2001;7:714-721.

30. Tesh RB, Arroyo J, Travassos da Rosa AP, et al. Efficacy of killed virus vaccine, live attenuated chimeric virus vaccine, and passive immunization for prevention of West Nile virus encephalitis in hamster model. Emerg Infect Dis 2002;8:1392-1397.

31. Ben Nathan D, Lustig S, Tam G, et al. Prophylactic and therapeutic efficacy of human intravenous immunoglobulin in treating West Nile virus infection in mice. J Infect Dis 2003;188:5-12.

32. Diamond MS, Shrestha B, Marri A, Mahan D, Engle M. B cells and antibody play critical roles in the immediate defense of disseminated infection by West Nile encephalitis virus. J Virol 2003;77:2578-2586.

33. Engle MJ, Diamond MS. Antibody prophylaxis and therapy against West Nile virus infection in wild-type and immunodeficient mice. J Virol 2003;77:12941-12949.

34. Griffin D, Levine B, Tyor W, Ubol S, Despres P. The role of antibody in recovery from alphavirus encephalitis. Immunol Rev 1997;159:155-161.

35. Levine B, Hardwick JM, Trapp BD, et al. Antibody-mediated clearance of alphavirus infection from neurons. Science 1991;254:856-860.

36. Dietzschold B, Kao M, Zheng YM, et al. Delineation of putative mechanisms involved in antibody-mediated clearance of rabies virus from the central nervous system. Proc Natl Acad Sci USA 1992;89:7252-7256

37. Kimura T, Griffin DE. Extensive immune-mediated hippocampal damage in mice surviving infection with neuroadapted Sindbis virus. Virology 2003;311:28-39.
38. Rammohan KW, McFarland HF, McFarlin DE. Induction of subacute murine measles encephalitis by monoclonal antibody to virus haemagglutinin. Nature 1981;290:588-589.

39. Seamer JH, Boulter EA, Zlotnik I. Delayed onset of encephalitis in mice passively immunised against Semliki Forest virus. Br J Exp Pathol 1971;52:408-414.

40. Shimoni Z, Niven MJ, Pitlick S, Bulvik S. Treatment of West Nile virus encephalitis with intravenous immunoglobulin (Letter). Emerg Infect Dis 2001;7:759.

41. Hamdan A, Green P, Mendelson E, et al. Possible benefit of intravenous immunoglobulin therapy in a lung transplant recipient with West Nile encephalitis. Transplant Infectious Disease 2002;4:160-162.

42. Haley M, Retter AS, Fowler D, Gea-Banacloche J, O'Grady NP. The role for intravenous immunoglobulin in the treatment of West Nile virus encephalitis. Clin Infect Dis 2003;37:e88-e90.

43. Manning A. Experimental West Nile drugs begin clinical trials. USA Today Final:D.10. September 9, 2003. Available at http://pqasb.pqarchiver.com/USAToday/402127301.html?did=40 $2127301 \&$ FMT $=$ ABS $\&$ FMTS $=$ FT $\&$ date $=$ Sep $+9,+2003 \&$ desc $=$ Experimental+West+Nile+drugs+begin+clinical+studies (accessed on March 1, 2004).

44. Smith AW, Matson DO, Stein DA, et al. Antisense treatment of caliciviridae: an emerging disease agent of animals and humans. Curr Opin Mol Ther 2002;4:177-184.

45. Cummings KJ, Lee SM, West ES, et al. Interferon and ribavirin vs interferon alone in the re-treatment of chronic hepatitis $\mathrm{C}$ previously nonresponsive to interferon: a meta- analysis of randomized trials. JAMA2001;285:193-199.

46. Medina J, Garci-Buey L, Moreno-Monteagudo JA, TraperoMarugan M, Moreno-Otero R. Combined antiviral options for the treatment of chronic hepatitis C. Antiviral Res 2003;60:135-143. 